\title{
Pengaruh Pemberian Penghargaan terhadap Kinerja Guru Honorer Sekolah Menengah Atas di Kota Sekayu, Musi Banyuasin, Sumatera Selatan
}

\author{
Iwan Kurniawan $^{\text {1* }}$, Edi Harapan ${ }^{2}$, Rohana ${ }^{2}$ \\ ${ }^{1}$ SMA Negeri 4 Sekayu, Musi Banyuasin, Sumatera Selatan, Indonesia \\ ${ }^{2}$ Universitas PGRI Palembang, Palembang, Sumatera Selatan, Indonesia \\ Corresponding author: Iwan Kurniawan (e-mail: $\underline{\text { ik871181@gmail.com) }}$
}

\begin{abstract}
Abstrak: Penelitian ini bertujuan mengkaji pengaruh pemberian penghargaan terhadap kinerja guru honorer pada sekolah menengah atas (SMA). Penelitian ini menggunakan pendekatan kuantitatif. Populasi penelitian yaitu seluruh guru honorer di delapan SMA di Kota Sekayu yang berjumlah 146 orang. 59 orang dari total populasi dipilih sebagai sampel menggunakan teknik simple random sampling dengan rumus Taro Yaname dan Slovin. Pengumpulan data menggunakan angket yang telah diuji validitas dan reliabilitasnya. Hasil penelitian menunjukkan bahwa kinerja guru honorer dipengaruhi oleh penghargaan yang diterimanya. Pemberian penghargaan kepada guru honorer berpengaruh signifikan terhadap kinerjanya, yaitu: (1) peningkatan tanggung jawab dalam mengerjakan tugas, (2) kesediaan bekerja melampaui standar kerja yang telah ditentukan, (3) semangat dan usaha yang tinggi untuk menyelesaikan tugasnya dengan baik, dan (4) kemauan dan kemampuan melaksanakan tugastugas administratif dan pengajaran.
\end{abstract}

Kata Kunci: guru honorer, kinerja guru, pemberian penghargaan

\section{The Effect of Rewards on the Teacher Performance at Senior High School in Sekayu City, Musi Banyuasin, South Sumatra}

\begin{abstract}
This study aims to examine the influence of rewards on the performance of honorary teachers in senior high schools. This research used a quantitative approach. The population is all honorary teachers in eight senior high schools in Sekayu city, which were 146 teachers. 59 teachers of the total population were selected as samples using simple random sampling techniques with Taro Yaname and Slovin. Data collection used a questionnaire that had been tested for its validity and reliability. The findings showed that the performance of honorary teachers was influenced by the rewards they received. Rewards to honorary teachers have a significant impact on their performance, namely: (1) increased responsibility in performing tasks, (2) willingness to work beyond predetermined work standards, (3) high spirit and effort to complete their tasks correctly, and (4) willingness and ability to carry out administrative and teaching tasks.
\end{abstract}


Keywords: honorary teachers, teacher performance, rewards

\section{PENDAHULUAN}

Guru sebagai subyek pendidikan sangat menentukan keberhasilan sebuah proses pendidikan. Fasilitas pendidikan yang lengkap dan canggih akan sulit untuk menghasilkan proses belajar dan pembelajaran optimal jika tidak ditunjang oleh guru yang berkualitas baik guru yang digaji pemerintah atau guru yang dibayar oleh sekolah, yang lazim disebut guru honorer. Dasar pengangkatan guru honorer yaitu Undang-undang Nomor 43 Tahun 1999 tentang perubahan atas Undang-undang Nomor 8 Tahun 1974. Kebijakan ini secara tegas menetapkan bahwa "pihak yang berwenang dapat mengangkat pegawai honorer" yang ditempatkan di berbagai instansi pemerintah, salah satunya adalah penempatan di lingkungan Kementerian Pendidikan dan Kebudayaan dan/atau Dinas Pendidikan dan Kebudayaan Provinsi dan Kabupaten/Kota.

Menurut Makarim (2020), saat ini guru honorer di Indonesia yang diangkat oleh Pemerintah Pusat berjumlah 658.214 (77,23\%). Selain itu terdapat sebanyak 190.105 guru tidak tetap yang diangkat oleh Pemerintah Daerah (Pemda) kabupaten/kota, 14.833 guru tidak tetap yang diangkat oleh Pemda Provinsi, dan 3.829 guru bantu pusat. Dari seluruh guru honorer tersebut, 80.907 orang $(25,26 \%)$ ada di jenjang pendidikan sekolah menengah atas (SMA), spesifiknya sebanyak 4.930 orang ada di SMA di Provinsi Sumatera Selatan (Imam, 2019) dan 146 orang ada di SMA Kota Sekayu. Jumlah guru honorer yang begitu banyak disertai dengan sistem perekrutan yang sembarangan mengakibatkan kualitas guru honorer tidak begitu baik. Namun demikian, kehadiran guru honorer dirasakan sangat membantu pelaksanaan pembelajaran di sekolah. Perekrutan guru honorer yang tidak sesuai dengan kebutuhan, justru menjadi akar permasalahan pendidikan nasional saat ini (Rahim, 2019).

Rendahnya kinerja guru honorer disebabkan oleh berbagai faktor internal dan ekternal. Menurut Sari (2016), terdapat dua faktor yang menyebabkan kinerja guru menjadi baik atau tidak baik, yaitu pemberian penghargaan dan motivasi. Saat ini, insentif yang diterima oleh guru honorer masih tergolong rendah sehingga belum dapat memenuhi kebutuhan hidup mereka. Upah guru honorer saat ini masih beragam, mulai dari Rp 150.000,-/bulan, yang sumber dananya disisihkan dari dana Bantuan Operasional Sekolah (BOS), hingga 1,3 juta per bulan sesuai dengan kebijakan masing-masing Pemda. Saat ini Pemda memberikan upah mengajar masih di bawah Upah Minimum Provinsi (UMP). Bagi guru honorer yang mengajar di jenjang SMA, besaran upah yang diterima sangat mempengaruhi kinerjanya. 
Kinerja guru honorer menjadi masalah tersendiri karena faktor upah yang didapat selama ini jauh dari cukup. Hal ini mengakibatkan rendahnya kinerja guru honorer di sekolah. Pemerintah pusat maupun Pemda belum serius memperhatikan kesejahteraan guru honorer. Insentif atau upah yang mereka terima tidak sebanding dengan pekerjaan yang mereka kerjakan dan tanggung jawab yang mereka pikul. Kondisi ini menunjukkan bahwa pada saat ini belum ada penghargaan yang diberikan kepada mereka. Keberadaannya di sekolah seperti sebagai "pelengkap penderita".

Meskipun tidak mendapat penghargaan dari Pemerintah Pusat, Pemda Provinsi, Pemda Kabupaten/Kota, dan sekolah tempat mereka mengabdi, guru honorer tetap bertahan pada status tersebut. Guru honorer memiliki motivasi untuk mengabdi saat ini, termasuk masih ada beberapa harapan dari pengabdian mereka yang tak berujung (Wirawan, 2009). Menurut Renesia (2019) terdapat banyak alasan bagi guru mau mengabdikan diri sebagai tenaga pengajar dan menurut Wirahadie (2020), minimal terdapat lima alasan seseorang memilih profesi guru, yaitu (1) kemampuan akademik, (2) status, (3) jaminan masa depan, (4) butuh pekerjaan, dan (5) profesi mulia. Beberapa alasan ini, pada umumnya yang memotivasi seseorang mau memasuki profesi keguruan.

\section{METODE PENELITIAN}

Penelitian ini dilaksanakan di SMA negeri dan swasta yang ada di Kota Sekayu. Penelitian dilaksanakan dari bulan Juni 2020 hingga bulan Januari 2021. Penelitian ini mengunakan metode kuantitatif dengan pendekatan survei yang merupakan salah satu metode yang banyak digunakan dalam penelitian sosial. Informasi dikumpulkan dari responden menggunakan kuesioner yang didistribusikan secara langsung atau melalui perantara seperti telepon atau media online. Langkah-langkah metode survei yang dilakukan adalah sebagai berikut.

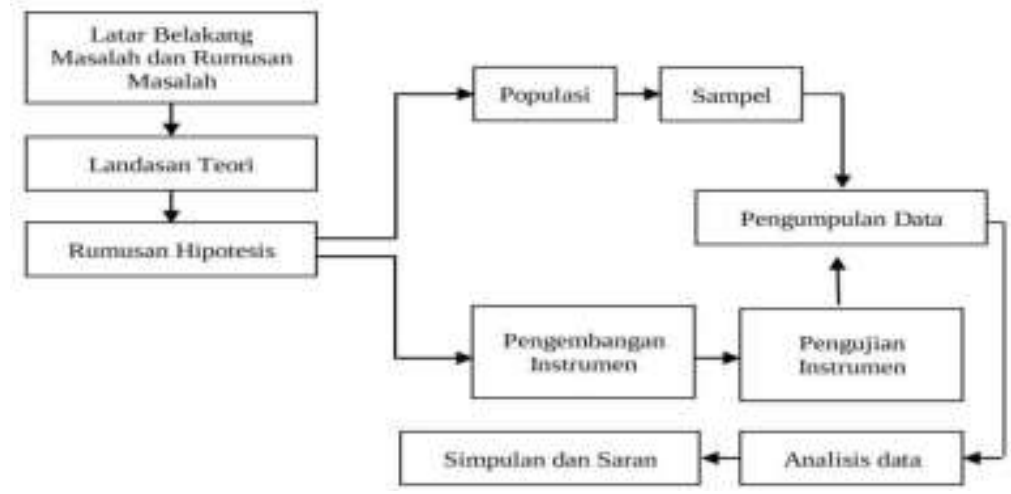

Gambar 1.Langkah penelitian survei 
Populasi penelitian ini meliputi semua guru honorer yang berjumlah 146 orang yang tersebar di delapan SMA. Penentuan sampel menggunakan teknik simple random sampling yang menghasilkan 59 responden. Rumus penghitungannya menggunakan Taro Yaname dan Slovin dengan presisi (tingkat kesalahan) 10\% sebagai berikut:

$$
n_{i}=\frac{N_{i}}{N} \cdot n \quad \text { dengan } n=\frac{N}{N \cdot d^{2}+1}
$$

Keterangan:

n : jumlah sampel

$\mathrm{N} \quad$ : jumlah populasi

$\mathrm{d}^{2} \quad$ : presisi yang ditetapkan

$\mathrm{N}_{\mathrm{i}} \quad$ : jumlah populasi menurut stratum

$\mathrm{n}_{\mathrm{i}} \quad$ : jumlah sampel menurut stratum, Riduwan (2011)

Pengumpulan data menggunakan teknik penyebaran angket penelitian. Berdasarkan uji coba angket diperoleh hasil semua butir pernyataan dari kedua variabel valid dan dapat dipercaya (reliabel) sehingga angket ketiga variabel tersebut dapat digunakan pada penelitian ini.

Teknik analisis data kuantitatif merupakan suatu kegiatan menganalisis data setelah data dari seluruh responden atau sumber data lainnya terkumpul. Teknik analisis menggunakan statistik dengan bantuan program SPSS for windows versi 22. Sebelum menganalisis pengaruh variabel bebas terhadap variabel terikat, uji persyaratan analisis yang meliputi uji normalitas, linieritas, multikolinieritas, dan autokorelasi dilakukan. Uji normalitas dilakukan untuk mengetahui normal atau tidaknya data masing-masing variabel dilakukan. Hasil penghitungan normalitas variabel kinerja guru honorer menunjukkan data variabel tersebut memiliki nilai signifikansi $0,200 *>0,05$. Ini berarti data penelitian berdistribusi normal. Hasil penghitungan normalitas variabel pemberian penghargaan menunjukkan bahwa data variabel pemberian penghargaan memiliki nilai signifikansi $0,200 *>0,05$. Ini berarti data pada penelitian ini berdistribusi normal.

Selanjutnya, uji linieritas digunakan untuk mengetahui apakah variabel yang diteliti memiliki hubungan yang linier atau tidak. Nilai signifikansi dari linierity penerimaan penghargaan sebesar $0.000<\alpha 0,05$ dan nilai signifikansi dari deviation from linierity sebesar $0,822 \geq 0,674$. Ini berarti ada hubungan yang linier antara pemberian penghargaan dengan kinerja guru honorer. Uji asumsi klasik ini dilakukan dengan pengujian multikolinieritas dan pengujian autokorelasi. Uji multikolinieritas bertujuan untuk membuktikan apakah pada model regresi ditemukan korelasi variabel bebas. Variabel bebas (pemberian penghargaan) 
mempunyai nilai tolerance $0.963>0.10$ dan nilai VIF $1,039<10.00$ sehingga dapat disimpulkan bahwa dalam model regresi ini tidak terjadi multikolinieritas

Uji autokorelasi merupakan pengujian dalam regresi untuk mengetahui bahwa nilai variabel dependen tidak berpengaruh terhadap nilai variabel itu sendiri. Hasil pengujian menunjukkan nilai Durbin Watson $(D W)$ sebesar 1,960. Ini berarti nilai tersebut berada di luar -2 sampai +2 atau tidak terjadi autokorelasi. Hasil pengujian menunjukkan bahwa ketiga variabel memenuhi unsur persyaratan sehingga analisis selanjutnya dapat dilakukan dengan menggunakan statistik parametrik. Langkah-langkah analisis data dimulai dari (1) analisis korelasi, (2) analisis determinasi, (3) analisis signifikansi, (4) analisis regresi linier sederhana, dan (5) pembuatan simpulan.

\section{HASIL}

Penelitian ini memerlukan pengolahan data dengan teknik statistik deskriptif. Data penelitian berasal dari dua variabel yaitu (1) kinerja guru honorer dan (2) variabel pemberian penghargaan.

\subsection{Kinerja guru honorer}

Hasil analisis variabel kinerja guru honorer menunjukkan bahwa kinerja guru honorer pada umumnya sudah “baik”. Hasil tersebut tergambar pada diagram batang berikut.

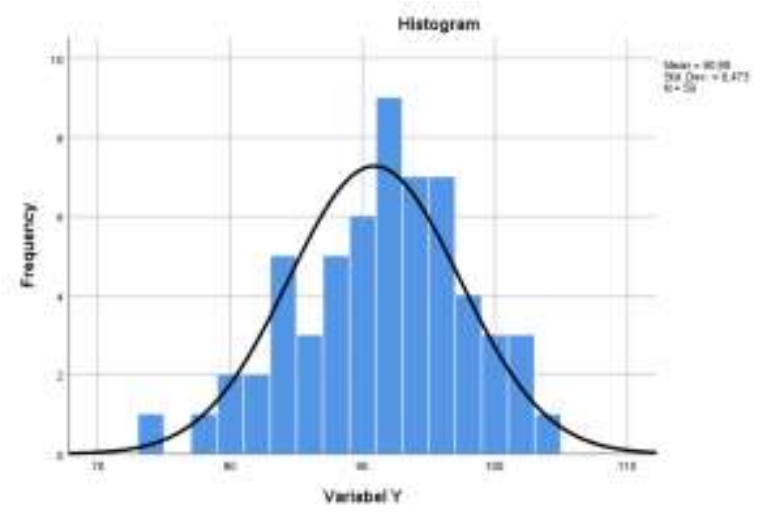

Gambar 2. Dia gram batang variabel kinerja guru honorer

Gambar diagram batang di atas mempunyai bentuk seperti kurva normal (berbentuk seperti lonceng). Hal ini membuktikan bahwa distribusi variabel kinerja guru honorer dapat dikatakan normal atau mendekati normal. Selanjutnya disajikan tabel total dan rerata jawaban angket variabel kinerja guru honorer sebagai berikut. 
Tabel 1. Total dan rerata jawaban angket varia bel kinerja guru honorer.

\begin{tabular}{|c|c|c|c|}
\hline No & Pernyataan & Total & Rata-rata \\
\hline 1 & $\begin{array}{l}\text { Saya hanya sebagai guru honorer, tapi sa ya sanggup mengerjakan tugas } \\
\text { seorang diri. }\end{array}$ & 223 & 3.78 \\
\hline 2 & Sa ya selalu sampaikan ide yang baik kepada pimpinan sekolah. & 239 & 4.05 \\
\hline 3 & $\begin{array}{l}\text { Saya sering tidak puas dalam menyelesaikan pekerjaan bila bekerja sama } \\
\text { dengan guru. }\end{array}$ & 231 & 3.92 \\
\hline 4 & $\begin{array}{l}\text { Sa ya membutuhkan kerja sama dengan guru senior lainnya dalam } \\
\text { menyelesaikan pekerjaan dalam hal-hal tertentu. }\end{array}$ & 254 & 4.31 \\
\hline 5 & $\begin{array}{l}\text { Sa ya a kan menyelesaikan tugas yang dibebankan kepada saya dengan } \\
\text { waktu yang telah ditentukan. }\end{array}$ & 251 & 4.25 \\
\hline 6 & $\begin{array}{l}\text { Sa ya berpendapat, tanggung jawab menyelesaikan tugas a dalah tanggung } \\
\text { ja wab mutlak bagi seorang guru. }\end{array}$ & 259 & 4.39 \\
\hline 7 & $\begin{array}{l}\text { Sa ya sela lu taat dengan perintah pimpinan, meskipun kadang-kadang } \\
\text { perintah tersebut bertentangan dengan batin saya. }\end{array}$ & 147 & 2.49 \\
\hline 8 & $\begin{array}{l}\text { Saya masih berstatus sebagai guru honorer, tetapi kejujuran merupakan } \\
\text { kepribadian yang tidak ternilai harganya. }\end{array}$ & 271 & 4.59 \\
\hline 9 & $\begin{array}{l}\text { Sa ya berprin sip, meskipun "la ngit a kan runtuh", tapikejujuran perlu } \\
\text { ditegakkan. }\end{array}$ & 277 & 4.69 \\
\hline 10 & $\begin{array}{l}\text { Saya menyiapkan administrasi kegiatan belajar mengajar di setiap a wal } \\
\text { semester. }\end{array}$ & 248 & 4.20 \\
\hline 11 & $\begin{array}{l}\text { Sa ya mengamati, masih banyak guru-guru yang tidak menyiapkan } \\
\text { adminisitrasi kegia tan belajar mengajar dengan baik. }\end{array}$ & 172 & 2.92 \\
\hline 12 & $\begin{array}{l}\text { Sa ya masih berstatus sebagai guru honorer, sa ya sela lu menyiapkan } \\
\text { perencanaan belajar mengajardi kelas. }\end{array}$ & 249 & 4.22 \\
\hline 13 & Saya terkadang tida k objektif dalam hal menilai hasil belajar. & 203 & 3.44 \\
\hline 14 & Sa ya sela lu merasa kasihan bila siswa sa ya mendapat nila irendah. & 139 & 2.36 \\
\hline 15 & $\begin{array}{l}\text { Sa ya melakukan penyiapan mengajar yang dirancang jauh sebelum } \\
\text { pelaksanaan pembelajaran dimulai. }\end{array}$ & 236 & 4.00 \\
\hline 16 & $\begin{array}{l}\text { Sa ya melihat, masih banyak guru honorer mengguna cara mengajar } \\
\text { kon vensional ya ng membosankan. }\end{array}$ & 177 & 3.00 \\
\hline 17 & $\begin{array}{l}\text { Sa ya sela lu menggunakan metode pengajaran yang berbeda-beda setiap } \\
\text { mengajardikelas. }\end{array}$ & 223 & 3.78 \\
\hline 18 & $\begin{array}{l}\text { Saya selalu mengikuti kegiatan workshop tentang pengajaran untuk } \\
\text { mengembangkan kemampuan diri. }\end{array}$ & 226 & 4.42 \\
\hline 19 & $\begin{array}{l}\text { Sa ya berpendapat, bagi seorang guru, kegia tan workshop penting untuk } \\
\text { diikuti a gar guru selalu mengikuti perkembangan dunia pendidikan. }\end{array}$ & 261 & 4.42 \\
\hline 20 & Sa ya selalu membuat karya ilmia h sederhana setiap tahun. & 179 & 3.03 \\
\hline 21 & $\begin{array}{l}\text { Sa ya mengamati, pada umumnya guru honorer didaerah tidak pernah } \\
\text { membuat karya ilmiah. }\end{array}$ & 191 & 3.24 \\
\hline 22 & $\begin{array}{l}\text { Sa ya tidak memiliki kemampuan membuat program pembelajaran karena } \\
\text { keterbatasan kemampuan yang sa ya miliki. }\end{array}$ & 220 & 3.73 \\
\hline 23 & $\begin{array}{l}\text { Setiap tahun ajaran baru, saya selalu membuat RPP perkembangan materi } \\
\text { pelajaran y ang sesuai dengan bidang ilmu yang saya tekuni. }\end{array}$ & 248 & 4.20 \\
\hline 24 & $\begin{array}{l}\text { Sa ya berpendapat, membuat pengembangan media in struk sional wajib bagi } \\
\text { seorang guru. }\end{array}$ & 238 & 4.03 \\
\hline \multicolumn{3}{|c|}{ Nilai Rata-rata } & 3.79 \\
\hline
\end{tabular}

Hasil analisis data variabel kinerja guru honorer menghasilkan skor terendah 74 dan skor tertinggi 103, mean 90,88, median 92,00, serta standar deviasi 6,473. Data pada tabel 1 menunjukkan bahwa kinerja guru honorer dari seluruh sub indikator memperoleh nilai ratarata sebesar 3,79 yang berada pada kategori baik. Jadi, keseluruhan indikator kinerja guru 
honorer berada pada kategori baik, yaitu berada pada interval 3,40 - 4,19 (Sudjana, 2015).

Dengan demikian, kinerja guru honorer SMA se-Kota Sekayu termasuk kategori baik.

\subsection{Pemberian penghargaan kepada guru honorer}

Hasil analisis variabel pemberian penghargaan menunjukkan bahwa penghargaan yang diterima oleh guru honorer berada padakategori “baik”. Hasil tersebut tergambar pada diagram batang berikut.

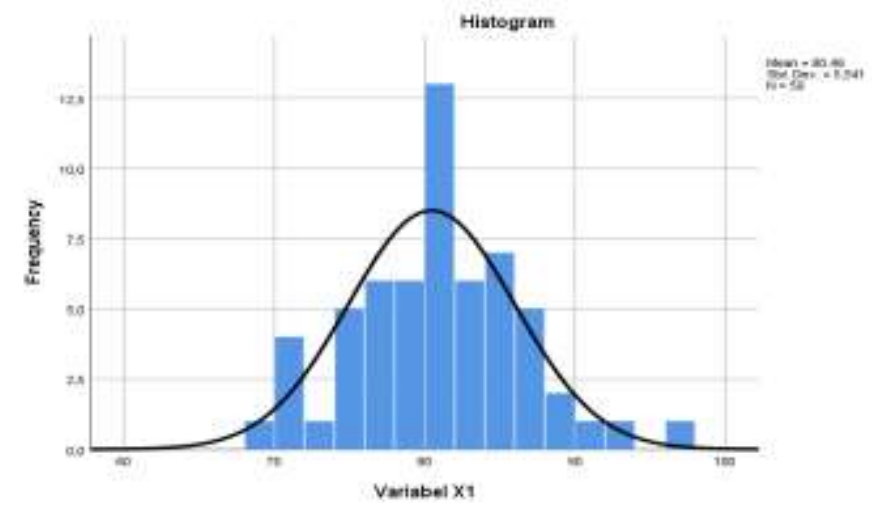

Gambar 3. Dia gram batang variabel pemberian penghargaan

Gambar diagram batang di atas mempunyai bentuk seperti kurva normal (berbentuk seperti lonceng). Hal ini membuktikan bahwa data berdistribusi normal atau mendekati normal. Berikut adalah total dan rerata jawaban angket variabel penerimaan penghargaan.

Tabel2. Total dan rerata jawaban angket variabel penerimaan penghargaan.

\begin{tabular}{|c|c|c|c|}
\hline No & Pernyataan & Total & Rata-rata \\
\hline 1 & $\begin{array}{l}\text { Saya berpendapat, setiap guru juga termasuk guru honorer tidak perlu } \\
\text { diberi penghargaan (reward). }\end{array}$ & 230 & 3.90 \\
\hline 2 & $\begin{array}{l}\text { Say a berharap reward merupakan pemotiv asi bagi guru-guru honorer } \\
\text { untuk meningkatkan kinerja. }\end{array}$ & 260 & 4.41 \\
\hline 3 & $\begin{array}{l}\text { Saya belum pernah mendapat reward dari siapa pun selama bekerja } \\
\text { menjadi guru honorer. }\end{array}$ & 169 & 2.86 \\
\hline 4 & $\begin{array}{l}\text { Saya terkadang mengharapkan reward dari pimpinan, walau berupa } \\
\text { ucapan terima kasih. }\end{array}$ & 204 & 3.46 \\
\hline 5 & $\begin{array}{l}\text { Say a belum pernah mendapat reward, tetapi guru-guru honorer yang } \\
\text { berprestasi a da yang diberi penghargaan. }\end{array}$ & 190 & 3.22 \\
\hline 6 & Say a bangga sekali, bila a da guru honorer y ang menerima reward. & 257 & 4.36 \\
\hline 7 & $\begin{array}{l}\text { Saya berpendapat, penerimaan reward daripimpinan merupakan pemacu } \\
\text { untuk bekerja lebih baik lagi. }\end{array}$ & 263 & 4.46 \\
\hline 8 & $\begin{array}{l}\text { Say a mengamati, seringkali unsur pimpinan beranggapan bahwa reward } \\
\text { itu sela lu dalam bentukmateri, sehingga mereka sulit untuk memberikan } \\
\text { reward. }\end{array}$ & 153 & 2.59 \\
\hline 9 & $\begin{array}{l}\text { Say a mempunyai prestasi kerja tidak pernah meningk at karena saya } \\
\text { tidak pernah mendapat reward dari pimpinan. }\end{array}$ & 227 & 3,85 \\
\hline 10 & $\begin{array}{l}\text { Saya mampu meningkatkan kinerja pembelajaran a salkan pimpinan } \\
\text { memberikan reward yang setimpal. }\end{array}$ & 148 & 2.51 \\
\hline
\end{tabular}




\begin{tabular}{|c|c|c|c|}
\hline No & Pernyataan & Total & Rata-rata \\
\hline 11 & $\begin{array}{l}\text { Saya memperhatikan guru honorer tempat sa ya bekerja selalu dianggap } \\
\text { seba gai “pelengkap penderita" yang tidak perlu diberi reward. }\end{array}$ & 220 & 3.73 \\
\hline 12 & $\begin{array}{l}\text { Saya mengamati, pimpinan selalu beranggapan bahwa guru honorer } \\
\text { hanya melaksanakan tugas sesuai dengan jam mengajar, jadi tidak patut } \\
\text { mendapat reward. }\end{array}$ & 223 & 3.78 \\
\hline 13 & $\begin{array}{l}\text { Saya membandingkan prestasi kerja guru honorer belum mampu } \\
\text { menyamai guru PNS. }\end{array}$ & 231 & 3.92 \\
\hline 14 & $\begin{array}{l}\text { Saya mengamati, guru honorer akan mendapat reward apabila memiliki } \\
\text { presta si kerja yang membanggakan. }\end{array}$ & 215 & 3.64 \\
\hline 15 & $\begin{array}{l}\text { Say a memperhatikan, dengan adanya pemberia } \mathrm{reward} \text {, kualitas kerja } \\
\text { menjadi meningkat. }\end{array}$ & 219 & 3.71 \\
\hline 16 & $\begin{array}{l}\text { Saya mengamati, sela ma ini kualitas kerja guru honorer belum ada yang } \\
\text { membanggakan. }\end{array}$ & 236 & 4.00 \\
\hline 17 & $\begin{array}{l}\text { Saya mempelajari, guru honorer y ang mendapatkan reward, beban } \\
\text { kerjanya melebihi guru PNS. }\end{array}$ & 162 & 2.75 \\
\hline 18 & $\begin{array}{l}\text { Saya mengamati, pada umumnya, volume kerja guru honorer memang } \\
\text { masih dibawah volume kerja guru PNS. }\end{array}$ & 203 & 3.44 \\
\hline 19 & $\begin{array}{l}\text { Say a masih berstatus sebagai guru honorer, tapi sa ya wajib loyal kepada } \\
\text { lemba ga tempat saya bertugas. }\end{array}$ & 251 & 4.25 \\
\hline 20 & $\begin{array}{l}\text { Saya tidak pernah mendapatkan reward, tapi sa ya loy al dengan profesi } \\
\text { ini (profesi keguruan). }\end{array}$ & 241 & 4.08 \\
\hline 21 & $\begin{array}{l}\text { Saya mengamati, a da guru honorermemasuki profesi ini seba gai "batu } \\
\text { lonca tan" saja sebelum diterima di instansila in. }\end{array}$ & 194 & 3.29 \\
\hline 22 & $\begin{array}{l}\text { Saya berpendapat, pimpinan wajib dihormati meskipun belum pernah } \\
\text { memberikan reward kepada sa ya. }\end{array}$ & 251 & 4.25 \\
\hline \multicolumn{3}{|c|}{ Nilai Rata-rata } & 3.66 \\
\hline
\end{tabular}

Hasil analisis data variabel pemberian penghargaan memperoleh skor terendah 69 dan skor tertinggi 96, mean 80,46, median 81,00. dan standar deviasi 5,541. Hal tersebut menunjukkan bahwa kinerja guru honorer dari seluruh sub indikator menunjukkan nilai ratarata sebesar 3,66 atau berada pada kategori baik. Jadi, keseluruhan indikator pemberian penghargaan berada pada kategori baik, yaitu berada pada interval 3,40 - 4,19 (Sudjana, 2015). Dengan demikian pemberian penghargaan bagi guru honorer termasuk pada kategori baik.

\subsection{Pengaruh pemberian penghargaan terhadap kinerja guru honorer}

Pengujian hipotesis yang diuji dalam penelitian ini sebagaimana telah dijelaskan pada bab sebelumnya, meliputi tiga langkah analisis yang dilakukan yaitu (a) analisis koefisien determinasi ( $\left.\mathrm{R}^{2}\right)$, (b) uji t, dan (c) persamaan regresi linier sederhana.

\subsubsection{Analisis Koefisien Determinasi $\left(R^{2}\right)$}

Pengujian hipotesis pengaruh pemberian penghargaan terhadap kinerja guru honorer diawali dengan penghitungan koefisien determinasi. Analisis koefisien determinasi $\left(R^{2}\right)$ ini bertujuan untuk mengetahui besaran persentase sumbangan pengaruh variabel bebas terh adap variabel terikat. Koefisien determinasi diperoleh dari nilai koefisien korelasi $(R)$ yang digunakan untuk 
mengukur kekuatan hubungan antara dua variabel yang hasilnya dapat dilihat dari ouput pada tabel model summary berikut ini.

Tabel 3. Model summary ${ }^{\mathrm{b}}$ koefisien determinasi $X_{1}-Y$

\begin{tabular}{lcccc}
\hline Model & $\mathbf{R}$ & $\begin{array}{c}\mathbf{R} \\
\text { Square }\end{array}$ & $\begin{array}{l}\text { Adjusted } \\
\text { R Square }\end{array}$ & $\begin{array}{l}\text { Std. Error of } \\
\text { the Estimate }\end{array}$ \\
\hline 1 &, $536^{\mathrm{a}}$ &, 286 &, 273 & 5,518 \\
\hline a.Predictors: (Constant), VariabelX1 \\
b. Dependent Variable: VariabelY
\end{tabular}

Nilai korelasi sebesar 0,536 a berada pada range 0.400 - 0.599 (Sugiyono, 2014). Nilai ini menunjukkan bahwa hubungan variabel pemberian penghargaan dengan kinerja guru honorer termasuk dalamkategori “sedang". Nilaipengaruh ( $R$ Square) pemberian penghargaan terhadap kinerja guru honorer sebesar 0.286 termasuk dalam kategori “sedang” karena berada pada range $0.10-0.29$ (Suwarno, 1998).

\subsubsection{Uji $t$ (uji parsial)}

Uji $t$ dilakukan untuk menguji hubungan, apakah signifikan atau tidak. Jika signifikansi kurang dari 0.05, variabel pemberian penghargaan mempengaruhi variabel kinerja guru honorer secara parsial. Hasil analisis uji signifikansi hubungan pemberian penghargaan dengan kinerja guru honorer disajikan dalam tabel 4 berikut ini.

Tabel4. Coefficients ${ }^{\mathrm{a}}$ variabel $X_{1}-Y$

\begin{tabular}{|c|c|c|c|c|c|c|}
\hline & \multirow{2}{*}{ Model } & \multicolumn{2}{|c|}{$\begin{array}{c}\text { Unstandardized } \\
\text { Coefficients }\end{array}$} & \multirow{2}{*}{$\begin{array}{c}\begin{array}{c}\text { Standardized } \\
\text { Coefficients }\end{array} \\
\text { Beta }\end{array}$} & \multirow{2}{*}{$\mathbf{T}$} & \multirow{2}{*}{ Sig. } \\
\hline & & B & $\begin{array}{c}\text { Std. } \\
\text { Error }\end{array}$ & & & \\
\hline \multirow[t]{2}{*}{1} & (Constant) & 40.627 & 10.545 & & 3.853 &, 000 \\
\hline & VariabelX1 & .625 & .131 & .535 & 4.777 & 000 \\
\hline
\end{tabular}

Pada tabel 4 diperoleh nilai $t$ sebesar 4.777 dengan taraf signifikan 0.000. Nilai $t_{\text {hitung, }}$ 4.777 kemudian dibandingkan dengan nilai $t_{\text {tabel }}$ pada signifikansi $0,05: 2=0,025$ dengan derajat kebebasan $(d f)=n-k$ atau $59-2=57(n=$ jumlah responden dan $k=$ jumlah variabel bebas). Hasil yang diperoleh untuk $t_{\text {tabel }}$ sebesar 2.000. Jika $t_{\text {hitung }}>t_{\text {tabel }}$ dan nilai signifikansi $<0,025$, maka $\mathrm{H}_{\mathrm{o} 1}$ ditolak dan $\mathrm{H}_{\mathrm{a} 1}$ diterima. Pada analisis ini, nilai $t_{\text {hitung }} 4.777>2.000$ dan nilai signifikansinya $0,000<0,025$. Ini berarti $\mathrm{H}_{\mathrm{o} 1}$ ditolak dan $\mathrm{H}_{\mathrm{a} 1}$ diterima. Artinya, pemberian penghargaan berpengaruh signifikan terhadap kinerja guru honorer SMA di Kota Sekayu. 


\subsubsection{Persamaan regresi linier sederhana}

Penentuan persamaan regresi linier sederhana didasarkan pada tabel coefficients dengan melihat data pada kolom unstandardized coefficients bagian " $\mathrm{B}$ " dengan rumusan $\mathrm{Y}=\mathrm{a}+\mathrm{bx}$. Nilai a diperoleh dari nilai constant sedangkan nilai b diperoleh dari nilai pemberian penghargaan. Dengan demikian, persamaan regresi liniernya adalah $\mathrm{Y}=40.627+0.625 \mathrm{X}_{1}$. Persamaan tersebut memiliki makna nilai konstanta sebesar 40.627. Artinya, jika pemberian penghargaan adalah nol, maka nilai kinerja guru honorer sebesar 40.627. Hasil penghitungan menunjukkan nilai variabel pemberian penghargaan $\left(X_{1}\right)$ sebesar 0.625 . Peningkatan satu satuan variabel pemberian penghargaan ini akan meningkatkan kinerja guru honorer sebesar 0.625 satuan dengan asumsi variabel penghargaan dalam posisi konstan.

\section{PEMBAHASAN}

Pada penelitian ini, peneliti menguji dan menganalisis dua variabel yang diteliti, yaitu kinerja guru honorer dan pemberian penghargaan guru honorer SMA di Kota Sekayu.

\subsection{Kinerja guru honorer}

Kinerja yang ditunjukkan oleh guru honorer merupakan kombinasi dari kemampuan, usaha, dan kesempatan yang dapat dinilai dari hasil kerjanya. Kinerja merupakan representasi tingkat keberhasilan seorang guru selama periode tertentu dalam melaksanakan tugasnya yang kemudian dibandingkan dengan berbagai kemungkinan, seperti standar hasil kerja, target atau sasaran dan kriteria yang telah ditentukan terlebih dahulu dan disepakati bersama. Stolovitch dan Keeps (2012) menyatakan bahwa kinerja sebagai seperangkat hasil yang dicapai guru setelah merujuk pada tindakan ketercapaian serta keterlaksanaan suatu pekerjaan yang diminta.

Keberadaan guru honorer sebagai pendidik dan pengajar pada semua jenjang pendidikan formal di suatu tempat memang sangat dibutuhkan pada saat ini. Meskipun statusnya guru honorer, mereka sangat dibutuhkan oleh sekolah. Status guru di Indonesia saat ini terbagi ke dalam dua jenis, yaitu guru tetap dan guru tidak tetap atau disebut guru honorer. Saat penelitian ini dilakukan, guru honorer di Kota Sekayu adalah guru yang belum berstatus sebagai Calon Pegawai Negeri Sipil (CPNS) berjumlah 146 orang yang tersebar pada 8 (delapan) SMA yang ada di Kota Sekayu.

Guru honorer hanya diberi honor mengajar per jam mata pelajaran. Bahkan, mereka diberi upah secara sukarela yang seringkali di bawah upah minimum yang telah ditetapkan secara resmi oleh Pemda Provinsi Sumatera Selatan. Selain itu, tidak jarang terjadi situasi 
berebut jam mengajar antara guru yang sudah bersertifikat profesi dengan guru honorer. Guru yang telah bersertifikat tentu saja mengharapkan terpenuhinya tugas pengajaran 24 jam perminggu. Guru honorer juga mengharapkan banyak jam mengajar karena ini berkaitan dengan jumlah honor yang akan mereka diterima.

Pengukuran kinerja guru honorer di lingkungan SMA yang ada di Kota Sekayu dilihat dari 4 (empat) dimensi, yaitu (1) kepribadian, (2) keterampilan teknik pengajaran, (3) metodologi pengajaran, dan (4) pengembangan diri. Setiap guru honorer harus memiliki beberapa kompetensi dasar, salah satu diantaranya adalah kompetensi kepribadian. Dimensi kepribadian dalam penelitian ini diukur dari dari 5 (lima) indikator, yaitu (a) prakarsa, (b) kerjasama, (c) tanggung jawab, (d) ketaatan, dan (e) kejujuran. Berdasarkan lima indikator tersebut, sebagian besar guru honorer SMA di Kota Sekayu telah menunjukkan kemampuannya dalam berprakarsa, mampu menjalin kerjasama dengan guru dan tenaga kependidikan lainnya, memiliki tanggung jawab yang tinggi akan tugas-tugas yang diembannya, memiliki ketaatan kepada pimpinan, dan memiliki kepribadian yang jujur.

Pada dimensi keterampilan teknis pengajaran, ada tiga indikator yang diukur, yaitu (a) terampil pada bidang administrasi dan kegiatan belajar mengajar (KBM), (b) terampil dalam bidang administrasi dan perencanaan proses belajar mengajar (PBM), dan (c) terampil menilai hasil belajar siswa. Berdasarkan ketiga indikator tersebut, diperoleh data bahwa guru honorer yang ada di SMA Sekayu sering tidak objektif dalammemberikan penilaian kepada siswa. Pada umumnya mereka memberikan nilai yang tinggi kepada siswa yang seharusnya mendapatkan nilai rendah. Hal ini atas pertimbangan "rasa kasihan" jika siswa tidak lulus pada mata pelajaran yang diampunya. Di sisi lain, guru honorer yang ada di SMA Kota Sekayu sangat disiplin dalam hal penyelenggaraan administrasi dan perencanaan kegiatan pembelajaran, termasuk dalam menyusun RPP setiap semester. Dengan demikian, kinerja seorang guru meskipun masih berstatus honorer ditentukan oleh lima kriteria tersebut. Mengingat tugas dan tanggung jawab seorang guru yang begitu kompleks, profesi ini memerlukan persyaratan khusus, antara lain (1) menuntut adany a keterampilan yang berdasarkan konsep dan teori ilmu pengetahuan yang mendalam, (2) menekankan pada suatu keahlian dalam bidang tertentu sesuai dengan bidang profesinya.

Variabel kinerja guru honorer pada dimensi pengembangan diri memiliki 4 (empat) indikator yang diukur, yaitu (a) mengikuti workshop, (b) membuat karya ilmiah, (c) mengembangkan program pembelajaran, dan (d) mengembangkan media instruksional. Guru 
honorer masih jarang diikutsertakan dalam kegiatan workshop. Pada umumnya, kepala sekolah menugaskan guru yang berstatus Pegawai Negeri Sipil (PNS) untuk mengikuti kegiatan workshop karena menyangkut masalah dana yang ada di sekolah. Permasalahan ini juga termasuk dalam hal membuat karya ilmiah, mengembangkan program pembelajaran, dan mengembangkan media instruksional yang masih lemah. Kewajiban membuat karya ilmiah baru diwajibkan kepada guru yang berstatus PNS karena menyangkut angka kredit untuk kenaikan pangkat dan jabatan. Pada dimensi pengembangan program pembelajaran dan pengembangan media instruksional, guru honorer diminta sebagai pembantu guru senior. Hal ini berhubungan dengan pengalaman mengajar dan penguasaan ilmu pengetahuan pada bidang masing-masing. Meskipun hal ini belum dianggap penting bagi guru honorer, mereka tetap perlu dilibatkan untuk memperkayapengalaman sebelum diangkat menjadi guru tetap. Artinya, guru honorer tersebut tanpa disadari sengaja dilatih untuk memperkuat kompetensinya sebagai calon seorang guru profesional.

Gomes (2005) menyatakan ada lima kriteria untuk menentukan kinerja seseorang yaitu (1) pengembangan diri, (2) kerja tim, (3) komunikasi, (4) jumlah produk yang dihasilkan, (5) keputusan yang diambil. Guru sebagai profesi memerlukan persyaratan khusus agar mampu menghasilkan kinerja tinggi. Tentu saja semua kriteria yang disampaikan oleh Gomes tersebut juga berlaku untuk semua guru, termasuk guru honorer. Indikator penilaian kinerja guru yang dapat dipergunakan untuk mengukur kinerja guru meliputi: (1) aspek kepribadian terdiri dari prakarsa, kerja sama, tanggung jawab, ketaatan dan kejujuran, (2) aspek teknis terdiri dari administrasi dan perencanaan kegiatan belajar mengajar, proses kegiatan belajar mengajar, penilaian hasil belajar, (3) aspek metodologi terdiri dari persiapan pengajaran, metode dan tahapan pengajaran, (4) aspek pengembangan diri terdiri dari keikutsertaan dalam berbagai pelatihan, seminar, karya ilmiah, pengembangan program dan pengembangan media instruksional (Usman, 2002).

Indikator pengukuran kinerja guru dalam penelitian ini sama halnya dengan indikator yang digunakan oleh Usman (2002) yang mengacu pada keempat aspek pengukuran tersebut sebagai pedoman dalam pembuatan instrumen pengukuran kinerja guru. Indikator kinerja guru dapat dikatakan baik apabila mampu melaksanakan penilaian kinerja. Hal ini senada dengan pendapat Kustiyah (2017) yang menyatakan bahwa kinerja guru dikatakan optimal jika indikator kinerjanya mencapai $75 \%$ kriteria yang ditetapkan. Hal ini juga terjadi pada guru honorer SMA yang ada di Kota Sekayu. 


\subsection{Pemberian penghargaan bagi guru honorer}

Penghargaan merupakan bentuk hadiah, ganjaran, penghargaan atau imbalan. Penghargaan yang diberikan kepada guru dapat berbagai macam. Secara garis besar penghargaan dapat dibedakan menjadi empat yaitu (1) pujian, (2) penghormatan, (3) hadiah, dan (4) tanda penghargaan. Selain itu, penghargaan yang diterima guru honorer SMA di Kota Sekayu juga berupa motivasi dari kepala sekolah dan rekan sejawat. Hal ini senada dengan pendapat Djamarah (2008). Menurutnya, bentuk-bentuk motivasi intrin sik yang dapat digunakan sebagai penghargaan kepada guru diantaranya (1) angka atau nilai numerik, (2) hadiah, (3) pujian, dan (4) hasil.

Pengukuran pemberian penghargaan di lingkungan SMA yang ada di Kota Sekayu dilihat dari lima dimensi, yaitu (1) penghargaan, (2) kebanggan, (3) prestasi, (4) produktivitas, dan (5) loyalitas. Dimensi penghargaan diukur dari dua indikator, yaitu (a) penghargaan itu sendiri dan (b) jenis-jenis penghargaan yang diterima oleh guru honorer. Berdasarkan angket yang disebarkan, sebagian besar responden menyatakan bahwa pemberian penghargaan di tempat mereka bertugas sudah baik. Artinya, penghargaan yang diterima oleh guru honorer di lingkungan SMA di Kota Sekayu cukup baik.

Guru honorer mendapat penghargaan ketika menunjukkan perilaku dan juga kinerja yang baik. Contohnya yaitu perilaku sopan yang ditunjukkan dalam kehidupan sehari-hari, keberhasilan dalam melaksanakan tugas-tugas pengajaran, dan lain sebagainya. Menurut Slameto (2010), penghargaan merupakan penghargaan yang diberikan guru sebagai hadiah karena guru tersebut telah berperilaku baik dan sudah berhasil melaksanakan tugas yang diberikan pimpinan kepadanya. Penghargaan juga diartikan sebagai alat untuk mendidik seseorang supaya mereka merasa senang karena perbuatan atau pekerjaannya mendapat penghargaan (Purwanto, 2011).

Analisis ini sejalan dengan temuan pada saat observasi dilakukan bahwa ada perasaan yang tidak adil, di mana guru honorer tidak mendapatkan fasilitas kerja yang sama dengan guru tetap lainnya, termasuk masa depannya yang belum jelas jika dilihat dari status kepegawaiannya. Guru honorer di Kota Sekayu tidak pernah tahu apakah merekaakan diangkat menjadi guru tetap atau menjadi guru honorer selamanya. Hingga saat ini, masih ada guru honorer yang sudah bekerja selama kurang lebih 20 tahun. Hal tersebut tentu membuat para guru honorer menjadi resah karena ketidakpastian status mereka. Hal ini tentu akan mempengaruhi kinerja mereka. 


\subsection{Pengaruh pemberian penghargaan terhadap kinerja guru honorer}

Motivasi guru honorer akan menurun apabila penghasilan yang diperolehnya tidak sesuai dengan hasil kerjanya. Tidak hanyaimbalan saja yang dapat menyebabkan kinerja guru honorer menjadi baik, namun juga faktor lain, misalnya status pekerjaan, profesi guru adalah profesi mulia di mata manusia maupun dihadapan Tuhan Yang Maha Kuasa.

Pemberian penghargaan bertujuan untuk meningkatkan produktivitas dan mempertahankan tenaga pendidik dan tenaga kependidikan yang berprestasi agar tetap loyal kepada sekolah tempatnya bertugas. Pemberian penghargaan dimaksudkan sebagai dorongan agar para guru tanpa terkecuali mau bekerja lebih baik dan membangkitkan motivasi sehingga mendorong kinerjanya menjadi semakin baik. Tohardi (2002) menyatakan bahwa penghargaan berupa ganjaran yang diberikan untuk memotivasi para pegawai (guru dan tenaga kependidikan) agar produktivitas kerjanya semakin meningkat. Penghargaan merupakan insentif yang mengaitkan bayaran dengan kinerja untuk dapat meningkatkan produktivitas para pegawai.

Pada umumnya, penghargaan yang diberikan kepada guru honorer SMA di Kota Sekayu hanya sebatas pujian.Pujian merupakan salah satu alat motivasi yang positif bagi setiap orang. Dalam kegiatan belajar mengajar, pujian dapat dimanfaatkan sebagai alat motivasi dari kepala sekolah kepada guru dan tenaga kependidikan yang dipimpinnya. Kepala sekolah dapat menggunakan pujian sebagai alat untuk menyenangkan hati para guru. Perhatian kepala sekolah kepada guru dapat membuat mereka merasa diawasi dan tidak akan berbuat sekehendak hatinya (Djamarah, 2008). Lebih lanjut, Djamarah menyatakan pujian dapat berfungsi mengarahkan kegiatan guru pada hal-hal yang mendukung tercapainya tujuan pengajaran serta menjadi umpan balik dari kepala sekolah. Pujian yang diberikan oleh kepala sekolah dan sejawat guru lainnya merupakan salah satu bentuk penghargaan yang paling mudah dilakukan. Pujian dapat berupa kata-kata, seperti bagus, baik, bagus sekali, dan sebagainya. Selain berupa kata-kata, pujian dapat juga berupa isyarat atau pertanda, misalnya dengan menunjukkan ibu jari, dengan menepuk bahu, dengan tepuk tangan, dan sebagainya.

Pemberian penghargaan juga dapat berupa penghormatan dari kepala sekolah, teman sejawat, maupun siswa dan orangtua/wali siswa kepada guru honorer SMA di Kota Sekayu. Secara teoritis, terdapat beberapa macam penghormatan, yaitu pertama, penghormatan berbentuk penobatan, yang diberikan orang yang layak mendapatkannya, diumumkan dan ditampilkan di forum pertemuan, teman satu kolega atau di depan orang tua siswa, organisasi profesi, dan sebagainya. Kedua, berbentuk pemberian kekuasaan untuk melakukan sesuatu, 
misalnya guru yang mendapat nilai tertinggi saat mengikuti pelatihan (workshop) dipilih sebagai ketua kelompok diskusi.

Penghargaan berupa tanda penghargaan disebut juga dengan penghargaan simbolis. Tanda penghargaan tidak dinilai dari segi harga melainkan dari segi kesan atau nilai kegunaannya. Misalnya yaitu pemberian sertifikat kepada guru teladan, guru berpres tasi, guru favorit, dan berbagai macam predikat lainnya. Ironinya, hingga saat ini belum ada guru honorer SMA di Kota Sekayu yang mendapat piagam penghargaan atas kinerjanya, prestasinya, maupun sumbangannya dalam mengharumkan nama sekolah.

Pada umumnya guru honorer mengharapkan penghargaan berupa hadiah dari kepala sekolah dan teman sejawat yang berujud barang (materi). Hadiah yang diberikan dapat berupa alat-alat keperluan bekerja, seperti laptop atau komputer, umroh, tabungan, dan sebagainya. Hadiah yang diberikan kepada orang lain sebagai penghargaan atau kenang-kenangan dapat berupa apa saja, tergantung dari keinginan pemberi. Kepala sekolah dapat memberikan hadiah kepada gurunya yang berprestasi saja, seluruh guru, sebagian guru, ataupun satu orang gu ru.

Hadiah diberikan setelah guru honorer menyelesaikan tugasnya dengan baik atau melebihi tugas yang menjadi tanggung jawabnya. Misalnya yaitu guru honorer mau dan mampu melaksanakan tugas-tugas administratif dan pengajaran di sekolah-sekolah yang kekurangan guru. Hal ini dapat membuat guru honorer lebih bersemangat dan berusaha untuk menyelesaikan tugasnya dengan baik. Pemberian penghargaan selajutnya dapat berupa angka atau simbol nilai dari hasil kerjanya. Angka yang diberikan kepada setiap guru bervariasi sesuai dengan hasil pekerjaan yang telah dilakukannya. Angka merupakan salah satu alat motivasi bagi guru untuk mempertahankan atau bahkan meningkatkan tanggung jawab dalam mengerjakan tugas. Contoh pemberian penghargaan berupa angka ini yaitu hasil Penilaian Pelaksanaan Pekerjaan (DP3) guru atau nilai yang diperoleh guru pada saat mengikuti Uji Kompetensi Guru (UKG), penilaian atas beban kerja guru selama satu semester, dan sebagainya. Angka yang diberikan menggambarkan hasil kerja guru honorer. Pemberian nilai berupa angka-angka kepada guru honorer memberikan manfaat yang sangat positif karena dapat mengetahui tingkat prestasi yang telah dicapainya.

Kepala sekolah dapat memilih beragam penghargaan agar sesuai dengan kondisi guru yang akan diberi dan juga keuangan sekolah. Kepala sekolah hendaknya juga dapat mengetahui siapa yang berhak mendapatkan penghargaan ketika akan memberikan penghargaan. Seorang guru yang menunjukkan hasil lebih dari biasanyamungkin pantas diberi penghargaan. Pada 
konteks ini, kepala sekolah hendaknya bijaksana sehingga pemberian reward tidak menimbulkan iri hati pada guru yang lain. Dengan demikian, secara umum penghargaan dapat kelompokkan menjadi dua macam, yaitu reward berupa non-materi (penghormatan, pujian, ucapan, sertifikat, dan gerakkan tubuh) dan berupa materi (uang, hadiah dalam bentuk barang, pemberian angka (nilai), dan tanda penghargaan).

Penghargaan yang diharapkan oleh guru honorer SMA di Kota Sekayu dapat berbentuk materi dan non-materi ketika mereka telah bekerja melampaui standar kerja yang ditentukan (Mahmudi, 2005). Penghargaan diberikan jika kegiatan organisasi mendapat kontribusi yang tinggi dari guru (termasuk guru yang berstatus honorer) dan tenaga kependidikan lainnya yang ada di sekolah. Pendistribusian penghargaan moneter dan non-moneter dapat secara langsung dan tidak langsung sesuai dengan kemampuan sekolah berdasarkan peraturan hukum yang berlaku (Schuler, 1987). Berkaitan dengan hal ini, Arikunto (1993) menjelaskan bahwa penghargaan merupakan sesuatu yang diberikan kepada seseorang karena sudah mendapatkan prestasi sesuai dengan yang dikehendaki. Penghargaan sebagai alat pendidikan diberikan ketika guru melakukan sesuatu yang baik atau mempersembahkan prestasi kerjanya. Menurut Djamarah (2008), penghargaan (hadiah) adalah memberikan sesuatu kepada orang lain sebagai penghargaan atau kenang-kenangan/cenderamata. Hadiah yang diberikan kepada orang lain dapat berupa apa saja, tergantung dari keinginan si pemberi. Bentuk penghargaan yang lain juga bisa disesuaikan dengan prestasi yang dicapai oleh seorang guru. Semua guru berhak menerima hadiah dari kepala sekolah dan rekan sejawat dengan motif tertentu. Oleh karena itu, penghargaan merupakan pemberian penghargaan dari kepala sekolah kepada guru, tenaga kependidikan, dan siswa.

Hasil analisis menunjukkan bahwa pemberian penghargaan memiliki hubungan yang signifikan dengan kinerja guru honorer. Hubungan yang ditunjukkan oleh kedua variabel termasuk dalam kategori sedang. Pengaruh yang disumbangkan oleh pemberian penghargaan terhadap kinerja guru honorer juga dalam kategori sedang. Pemberian penghargaan terhadap guru honorer berdampak positif yaitu (1) peningkatan rasa tanggung jawab guru dalam mengerjakan tugas, (2) kesediaan bekerja melampaui standar kerja yang ditentukan, (3) semangat dan usaha untuk menyelesaikan tugasnya dengan baik, (4) kemauan dan kemampuan melaksanakan tugas-tugas administratif dan pengajaran. Pengaruh pemberian penghargaan terhadap kinerja guru honorer berasal dari dimensi penghargaan yang diterimanya, kebanggaan akan prestasinya, prestasi kerja yang mampu dicapainya, produktivitas kerja, dan loyalitas kepada organisasi atau lembaga pendidikan. 


\section{SIMPULAN}

Pemberian penghargaan kepada guru honorer di SMA di Kota Sekayu berhubungan signifikan dengan kinerja guru honorer. Secara parsial, pemberian penghargaan berpengaruh signifikan terhadap kinerja guru honorer meskipun pengaruh yang disumbangkan termasuk dalam kategori sedang. Penghargaan yang diterima oleh guru honorer SMA di Kota Sekayu pada saat ini termasuk dalam kategori baik. Sebagian besar reponden menyatakan bahwa pada umumnya mereka telah diberi penghargaan oleh kepala sekolah dan teman sejawat. Penghargaan yang paling diharapkan oleh guru honorer SMA di Kota Sekayu berupa kenaikan gaji (uang) dari hasil kerja dan prestasi yang mereka sumbangkan kepada sekolah. Penelitian ini menyarankan kepala sekolah pemerintah provinsi dalam hal ini Dinas Pendidikan dan Kebudayaan Provinsi Sumatera Selatan untuk memberikan penghargaan kepada guru honorer untuk meningkatkan kinerjanya.

\section{DAFTAR PUSTAKA}

Arikunto, S. (1993). Manajemen pengajaran secara manusiawi. Jakarta: PT Rineka cipta Djamarah. S.B. (2008). Psikologi belajar. Jakarta: Rineka Cipta.

Gomes, F.C. (2005). Manajemen sumber daya manusia. Yogyakarta: Andi Offset

Kline, D. (2020, June 21). Pengertian metode penelitian survei. Retrieved from https://ranahresearch. com/ pengertian-metode-penelitian-survei/

Kustiyah. (2017). Meningkatkan prestasi kinerja guru melalui supervisi akademik kepala sekolah dengan pendekatan individual di SD Candi 01 Kecamatan Candisari Kota Semarang semester ii tahun pelajaran 2013/2014. Malih Peddas, 7(1). 11-20.

Mahmudi. (2005). Manajemen kinerja sektor publik. Yogyakarta: UPP AMP, YKPN.

Makarim, N. (2020, January 29). Tenaga honorer akan dihapus, berapa jumlah guru non -PNS?. Katadata. Retrieved from https://katadata.co.id

Purwanto. (2011). Evaluasi hasil belajar. Yogyakarta: Pustaka Pelajar.

Rahim, R. (2019, December 17). IGI sebut jumlah guru honorer jadi akar masalah pendidikan. CNN. Retrieved from https://www.cnnindonesia.com/nasional/20191216195949-20457543/igi-sebut-jumlah-guru-honorer-jadi-akar-masalah-pendidikan

Riduwan. (2003). Dasar-dasar statistik. Bandung: Alfabeta.

Sari, W.P. (2016). Pengaruh gaji dan motivasi terhadap kinerja guru pada SMA swasta Binembah, Rokan Hilir, Riau. Tingkap: Jurnal Ilmiah Ilmu-Ilmu Sosial Budaya \& Ekonomi, 12(1), 65-81.

Schuler, R.S. (1987). Performance based teacher educational: Suatu alternatif. Jakarta: Binarupa Aksara.

Slameto. (2010). Belajar dan faktor-faktor yang mempengaruhinya. Jakarta: Rineka cipta.

Stolovitch, H.D \& Keeps, E.J. (2012). Handbook of human performance technology a comprehensive guide for analysis and solving performance problem in organization. San Fransisco: Jersey-bass Publisher.

Sudjana. (2015). Metode statistika. Bandung: Tarsito. 
Suwarno, B. (1998). Pengukuran pengaruh dalam ilmu statistik. Bandung: UPI.

Tohardi. A. (2002). Pemahaman praktis manajemen sumber daya manusia. Bandung: Mandar Maju.

Undang-undang No 43 Tahun 1999 tentang Pokok-Pokok Kepegawaian. Agustus 12, 2020.https://pih.kemlu.go.id/files/UU_Pokok-pokokKepegawaian-Perubahan_No.43 Th.1999.pdf

Undang-undang No 20 Tahun 2003 Tentang Sistem Pendidikan Nasional. Agustus 25, 2020. https://sipuu.setkab.go.id/PUUdoc/7308/UU0202003.htm

Undang-undang Nomor 8 Tahun 1974 Tentang Pokok-Pokok Kepegawaian. Agustus 12, 2020. https://ngada.org/uu 8-1974bt.htm

Usman, B.(2002). Media pendidikan. Jakarta: Ciputat Press.

Wirahadie. (2020, March 2). Lima alasan seseorang memilih profesi guru. Artikel ilmiah populer. Retrieved from https://wirahadie.com/5-alasan-seseorang-memilih-profesiguru/

Wirawan. (2009). Evaluasi kinerja sumber daya manusia: Teori, aplikasi, dan penelitian. Jakarta: Salemba Empat. 